\title{
The Shifting Cultivation of Bauma Tahutn Tradition in the Dayak Kanayatn People in West Kalimantan
}

\author{
Saiful Bahri ${ }^{1}$, Nana Supriatna ${ }^{2}$, Helius Sjamsuddin ${ }^{3}$, Erlina Wiyanarti ${ }^{4}$ \\ ${ }^{1}$ Social Education Study Program, SPs Universitas Pendidikan Indonesia; \\ ${ }^{2,3,4}$ School Postgraduate Studies Universitas Pendidikan Indonesia \\ ${ }^{1}$ Corresponding email:bangipoelponty@gmail.com
}

\begin{abstract}
The purpose of this study is to know the shifting cultivation of local wisdom Bauma Tahutn tradition in the Dayak Kanayatn People in West Kalimantan. The Bauma Tahutn Tradition in the Dayak community can adapt to the natural environment through local genius that they have and practiced for generations. The ability of the Dayak community to read the signs of nature becomes a strength of local communities to live harmoniously, harmoniously and in balance with the environment. The research method used in this research is ethnography method, the location of the study was conducted in Dayak Kanayatn community in Ambawang River District of Kubu Raya Regency of West Kalimantan Province. Data collection technique in research is obtained through in-depth interview, observation participant, documentation study. The results of research and data analysis show that: Bauma Tahutn tradition is a cropping pattern with shifting cultivation system. The Dayak farming system uses land that is usually cultivated two to three times during the growing season. The fact that traditions cultivate as an integral part explains the identity of Indigenous Dayak communities. The fact that traditions cultivate as an essential part explains the uniqueness of Indigenous Dayak communities.
\end{abstract}

Keywords: Shifting Cultivation, bauma tahunt tradition, Local wisdom, Local genius, Dayak Kanayatn.

\section{Introduction}

Deforestation or exploitation of forest areas for plantations, forest fires and the draining of peatlands are the main causes of emissions in Indonesia. Similarly, the deforestation rate reaches 2 million hectares and this condition places Indonesia as the first country with the highest deforestation rate in the world (Gellert, 2005: 1356). The forests of West Kalimantan are already visibly transformed, which was once green by large trees now green by the dominating palm oil plantations. Community-based forest management and conservation is only a matter of sustainable and sustained local wisdom to address climate change and the global crisis.

Climate change as a result of the global warming process, the accumulation of greenhouse gas emissions (GHG) continues to roll and is ongoing until today. Changes in global climate conditions are believed to experts as the impact of human activities. Such human intervention measures are in the form of burning of fossil fuels and the process of transfer of forest area functions which further contribute to the accumulation of global emissions. Humans tend to produce exploitative activities so as to enlarge the occurrence of environmental damage. In the theory of environmental ethics, anthropocentrism views man as the center of the system of the universe. Humans and their interests are considered the most decisive in the ecosystem order and its relation to nature (Keraf, 2010: 47). To return to the balance of human life, the way out according to perenealism is to return to the values (back to value) that underlies human life at first. (Tapung, 2013; 159).

In Capra's thought (2002: 12), problems in life can not be understood separately. The problem of life is a systemic problem, meaning that life is made up of components that are all interconnected and dependent on one another. The practice of natural resource management is inseparable from the value system and rules of life in the socio-cultural order which furthermore becomes the source of wisdom in maintaining the balance of living creatures with nature and God. In this condition, harmony in harmony with nature, God and fellow human beings mandate and spirit of the local value system in maintaining the synergy and the integrity of creation.

In the process, there is traditional knowledge, solidarity, togetherness, spirituality, local wisdom and anticipatory attitude. Through this hereditary activity, the knowledge and practice of local wisdom of hereditary heritage still color the way of life of 
farming done an Indigenous Dayak community. Dayak Indigenous People in Kalimantan, especially in West Kalimantan since the early ancestors of the Dayak community have been struggling with the opening of paddy fields for sustainability through cultivation. The activities of farming are generally done jointly involving both women and men and children. The practice of farming is also marked by a number of rituals as an expression of gratitude, thanks, thanks to salvation and fortune. Farming activity is a business practice on the management of surrounding natural resources that are done down descend.

The practice of farming inherited heritage is not just an attempt to fulfill (the right to) food alone, but also as part of the life cycle and even the heart for the sustainability of community life. The fields that are done with the terms, values, and customs are contained therein. Therefore, it is essentially a "civilization" for the life of Dayak people. For indigenous Dayak people believe that "Our Land, Our Life", the land and the natural environment are the source of life that is very meaningful in all aspects of life. Some of them likened the earth as their mother. Damaging nature is the same as hurting their mother. Likewise, if it pollutes the earth. The fact of such prudence can be seen from the seven principles of natural resource management by Dayak Indigenous Peoples by combining aspects of independence, sustainability and benefit, that is: 1) continuity; 2) togetherness; 3) natural (does not know chemicals); 4) spirituality; 5) process (always marked ritual procession); 6) subsistence; and 7) customary law.

Cultivating in this case the authors more specifically call it the term Bauma Tahutn is part of the farm itself. Bauma Tahutn is a process that is of course not as simple as imagined. Bauma Tahutn is one of the local wisdom of Dayak people, especially in West Kalimantan and it is very unfair if local wisdom held by Dayak people is considered as forest destroyer by burning forest. Bauma Tahutn is a cropping pattern with shifting cultivation or in terms of shifting cultivation. The Dayak farming system uses land that is usually cultivated two to three times the growing season. The fact that the tradition of farming as an integral part of explaining the identity of indigenous Dayak communities is unlikely to be eliminated even in the fact that the habit of opening up the shifting cultivation is gradually eroded by the lands that have switched its designation.

\section{Methods}

The method of research in the first stage is the study of ethnography. Ethnographic studies are part of a qualitative approach. This study aims to examine the values of Bauma Tahutn tradition of West Kalimantan Dayak community. According to Creswell (2013: 462), Ethnographic designs are qualitative research procedures for describing, analyzing, and interpreting a culture-sharing group's shared patterns of behavior, beliefs, and language that develop over time. Thus ethnographic research is a qualitative study that examines the life of a group/society scientifically which aims to study, describe, analyze, and interpret the cultural patterns of a group in terms of behavior, beliefs, languages, and shared views. In this research, the researcher chose the critical ethnography type.

The type of participant observation that the researcher chooses is an active participant observation, so in this observation, the researcher arrives at the place of the observed person's activity and participates in the activity. This technique is used to collect data about traditional values of West Kalimantan Dayak Bauma Tahutn Society. These observation activity researchers conducted prior to conducting research that is by making observations associated with traditional values Bauma Tahutn Dayak West Kalimantan. Initial observation by the researcher is enough and get more than enough supplies, then the data obtained from the observation that the author use for more research stock in more depth and detail by using the next stage of the interview. This interview is used to find out (1). The tradition of Bauma Tahutn cultivation, (2). The process of implementing the Bauma Tahutn tradition, (3). The values of local wisdom Bauma Tahutn tradition. In this case, the researchers conducted interviews with some informants selected based on the criteria or categories of Dayak ethnic who perform Bauma Tahutn tradition. The details of the informants are as follows: 


\section{Results and Discussion Bauma Tahutn Tradition}

Bauma Tahutn is a unique culture because it has the meaning of philosophy of togetherness and kinship. Farming with a farming system is a form of agricultural processing that has characteristics such as rotation of fields, cleaning with fire, no animal pullers, and fertilizers. Farming with a farming system is a form of agricultural processing that has characteristics such as rotation of fields, cleaning with fire, no animal pullers, and fertilizers. Man becomes the only power, simple processing tools. Planting rice paddies aims to produce rice for consumption purposes, family subsistence or farming household itself. The picture of rice field cultivation (Bauma Tahutn) is as follows.

The second offering is directed to a spirit called tuwajaq that is in all corners and corners of the field. In the rice planting ritual, it is disclosed how the cultivators expect supranatural world interference. Through this ritual, the cultivators rested on the fate of the fields and the seeds of the rice that they planted under the protection of good spirits, especially the spirit of the ancestors. The cultivator asks the spirits both through offerings to protect fields and rice from the disturbance of evil spirits.

The purpose of the above ritual proves that the Dayak people in Kalimantan as well as other indigenous peoples, essentially have a holistic perception of nature. For them, the forest is not only economically meaningful but also socio-cultural relegius. Not only do they contain only a variety of plants and animals, but they themselves are part of an inseparable forest, and the forests in their sovereign territory have clear and legally established property rights (Widjono 1998: 67-68).

The main equipment here is tugal and seed or mountain seeds. Tugal is a tool for making rice seed pits on farmland. Men make seed holes, and women put seeds or seeds into them. Planting rice is done at the end of August until the end of September. Both of these months are generally fixed with the rainy season. Traditionally, the time to plant rice fell on the moon and stars called bafit, karooq, and tigaq. In the month of bafit, the common man begins to plant rice. The karoq moon is the best month to grow rice, but it is considered a bad time. It is expected that at this stage the rainy season comes normally to allow the rice to grow properly. In addition, it is expected that this work is completed in one day with the help of many people. And the cultivation of rice itself is done by mutual cooperation.

The above shifting system is a model of traditional wisdom in forest management. On this basis, Widjono (1998: 77) explicitly states that Dayaks who can not farm can be doubted characteristic of Dayak because they have been uprooted from the roots of ancestral culture. Ave and King (in Arman 1994: 129), suggested that the Dayak sifting cultivation or swidden traditions have been practiced since the time of their ancestors who were the main livelihoods. Sellato (1989) in Soedjito (1999: 115), estimates that the Dayak farming system started two centuries ago. Even Mering Ngo (1990), mentioned the way of farming life in various areas in Borneo has been known 6000 years before Christ.

\section{Stages of Shifting Cultivation Bauma Tahutn Tradition}

The stages in planting rice with cultivation (Bauma Tahutn) through several stages of Bahaupm is the first stage conducted in the cycle of farming activities by community communities. Bahaupm means deliberation or joint meetings conducted to discuss preparation or planning to open the Bauma Tahutn (field). In the event bahaupm, in particular, is usually done to discuss the preparation of the next activity that is baburukng. The event itself is usually done at home and led by Tuha Tahutn, a traditional elder who is specifically given the mandate as a leader to coordinate the organization of farming activities in the community.

Baburukng. The customary rituals performed in Paburukngan (read: Paburungan) are intended as a form of gratitude, asking for blessings as well as the form of bases (respect/permission) to the natural ruler by way of bapadah that will be done shifting cultivating activities. The ritual process of this customary ritual is usually led by traditional elders known as Panyangahatn. Called (custom ritual) baburukng, because on this occasion, residents also usually make direct instructions or messages from nature through the sound of certain birds such as the voice of buria' or keto is believed to imply a special message with regard to the situation throughout the process of farming activities that will be done later. The sounds of birds that are heard in front of 
or from the rising sun usually indicate a good sign and if coming from the back means not good.

Balala' is an important stage in which people practice abstinence. In the activities performed after this baburukng ritual, abstinence is done in the form of balala' body or balala' tamakng is residents for one day should not leave the house. In addition, for three days residents also abstain from doing ngalayu' activities and not go to the fields. Activity ngalayu' referred to the action of picking or making leaves and or plants so withered. In addition, it is usually not allowed to kill a bloody animal. Violations of balala' activities 'are believed to be, in addition to adversely affecting the decline of crop yields due to pest disturbance and the like, violations of abstinence can also affect the disruption of the health condition of the community in the community as well as to tuha tahutn as the balala' tradition stakeholders.

Ngawah this is done for ngakoi 'abut that determines the location at once pleads (bapadah) by way of offering (basampakng) that will start farming (bauma tahutn) through slashing activities. Site selection for farming usually avoids peatland clearance. In addition to rice that will be planted will not be good because the source of food is not much, on peatlands are also believed to be more sources of pests that potentially threaten rice crops such and other types of rice disturbance. In the process of ngawah, in addition to bringing the completeness of rituals of betel lime, rice and salt to be placed on the location to be used as fields, residents usually also make a stake resembles kalakakng as a sign that the location has no owner. When ngawah, residents just slashed his ears and marked the location to be made into fields. In the activities of nukwah especially during slashing, the sound of certain birds such as keto and buria' avoided so as not to suspect' or sungkak.

Nabas is the stage of clearing the land by slashing shrubs and a number of small diameter wood plants in the location to be covered. This activity is usually done by involving other residents through the balale' way in an ale'atn group. Slashing is usually done by using the iso 'slash tool. This activity involves a number of women and men who are performed together with the same work portion.
Nabank means (cutting down) a process that is done by cutting down the standing of a tree in a field location to be cleaned. The process is usually also done jointly by involving a number of other people/residents through the activities of balale' by ale'atn this group, using a very simple tool. Largediameter logging activities are generally performed by adult males. While women usually cut small timber and help prepare meals together when this process takes place. Equipment used for nabakng the ax.

Ngaradah is the stage of farming done by cutting or cutting branches and branches of wood that has been cut to be more orderly and look neat. In addition, the wooden branches that are trimmed (contained) will dry faster, making it easier for the next process when doing the land clearing by way of burning. Ngarangke is part of the stages after ngaradah to wait for the right time to burn. In this process, shrubs, trees, and twigs that are cut and cut (dried) are allowed to dry until finally ready to be cleaned by means of fuel.

Ngalaet/Ngaradak is very important and must be done to control the fire in the process of burning the fields. Ngaradak or ngalaet is done by cleaning the edges around the field width 1 to 3 meters so that when the process of burning is done, the fire does not spread outside the field. Ngalaet process is usually also known as nataki' or make panatak. This activity can be done with balale' through the ale'atn group, but can also be done individually by the owner of the field or commonly known as nonokng.

Nunu means burning. This stage is a clearing of fields that are done by burning. In addition to having traditional technical knowledge related to doing so in a controlled manner, the cultivation community usually also prioritizes the prudence in clearing the fields in this way. Such knowledge and caution are manifested through the involvement of a number of people, both family members and landowners side by side with the fields to be burned. Even the nunu process can also usually be done by involving aleatn groups through balale' activities. At the stage of cleaning the field by means of fuel, the cultivators are very concerned about weather conditions and wind direction. In this process, wind is still needed to produce a good burn. Burning is done in the afternoon around $3 \mathrm{pm}$ to $5 \mathrm{pm}$, or when the wind is considered to begin to decrease. On the 
other hand, technically the burning of the fields is done against the direction of the wind.

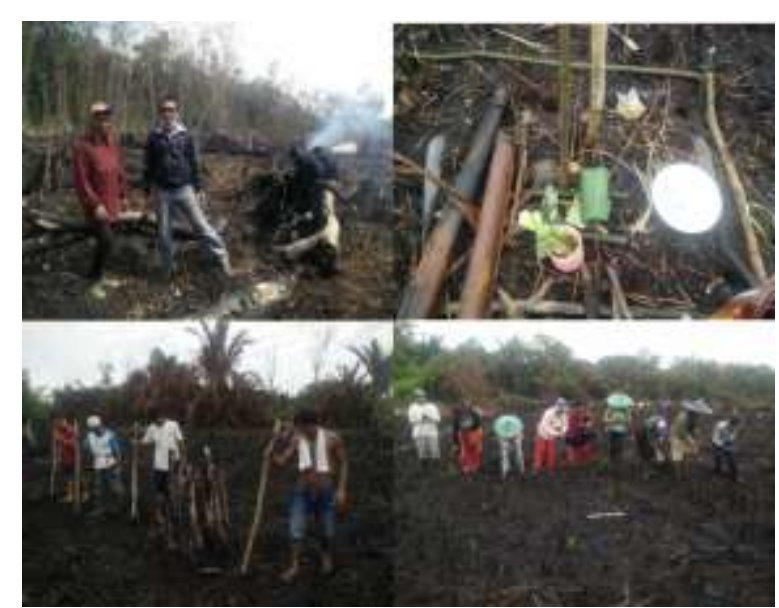

Figure 1. Stage of cleaning the rest equipped with offerings (sekapur sirih) and stage of cultivation activities (Resource: Researcher 2017)

Ngalese' is the stage of cleaning the rest of the trees, branches, and twigs on the fields after being burned by cutting and or collecting wood/twigs of burnt remains to be stacked and then burned again. Ngalese' activities are usually done individually by landowners (nonokng) and or commonly done jointly involving other residents through balale' activities, especially if burnt fields still leave plenty of unopened trees, branches, and twigs. There are times when fields that are burned into manta 'or not scorched.

Nugal is a stage of cultivation activities that is done by planting and sowing the seeds of rice on the ground that is perforated by using tugal. The spirit of togetherness in this process is evident from the involvement of roles between women and men. In this case, the adult male usually plays a role in making the rice planting hole on the ground using tugal made of sharpened wood. While women usually play a role in sowing seeds on each hole Tugal while carrying and or wearing a container storage of seeds known as topokng Pamanih.

Ngabat Lubank Tugal is a ritual performed so that the planted rice grows nice and sturdy, not easy to fall. This activity is done when the sowing rice has grown about $15 \mathrm{~cm}$ to $30 \mathrm{~cm}$. This stage is also known as "ngabat lubakng tugal" with the meaning of rice that is scattered from the tugal hole. This ritual is usually done in the middle of the field ie in pangkalatn/pabanihan

Ngalingkat and Nyulat is the stage that is done to break up the plant grown rice that grows thick to be planted in the fields that are rare or not overgrown with rice. While the nyulat is the stage where rice seedlings are planted in the fields of is not overgrown with rice during the first planting. At this stage, it is generally done by the owner of the field by doing it yourself (nonokng). However, it can also be done jointly through balale' activities by ale'atn groups.

Ngarumput is the process of clearing the grass that grows in the fields. Besides being done together with balale', the process of cleaning the grass is done naturally-manually, without the use of chemicals. This activity is usually done by grasping the grass with the hands directly or by using a lawn mower that is usually called sobe' and or iso'enek or tongkekngan. Grass season is usually done when the rice has grown knee or higher than the knee.

Ngiliriant or eap is a waste of rice disease so that various pests do not interfere through a series of customary rituals led by a traditional elder (Panyangahatn) and also attended by traditional elders such as the tuha tahutn, panyanakng kalangkakng, and some residents. Ngiliratn done is also intended to restore the disease of rice so as not to disrupt the growth of rice grown. In this ritual, rice disease is returned to its origin.

Mupusatn is part of the step of farming done with marked a ritual intended to fulfill/cultivate the process of cravings so that the fruit produced is good and contained. In this case, race is likened to humans who crave while being pregnant with the fetus. The process of mupusatn is done when the rice flowers start out or in the local language, the term is called mure. This mupusatn custom ritual is performed in the middle of the field by installing a pabayo equipped with a betel vine led by a prayer leader (Panyangahatn).

Nurutni' is the first stage of the mature rice harvest. Usually begins with a customary ritual procession baremah. It is meant to convey the message to God who has lowered the rice. While bahanyi is the next stage done to harvest the rice that has been mature to complete. At the stage of nurutni 'rice harvest is done not long, but when bahanyi harvest of rice done until the sunset. Rice harvesting 
activities are generally done using a tool called katam. While the place to store the picked rice stalks use a place known as inge. While the place to store the picked rice stalks uses a place known as inge. Nurutni' is usually done by involving a number of other residents through joint work activities (balale'). But some are doing it themselves by way of nonokng.

Makatn nasi' Barahu is an important stage that reflects the high spirit of sharing and solidarity. This process is also known as ngalantekatn. At the stage accompanied by this traditional ritual procession, the people who make the event usually cook and serve the rice 'poe' and rice 'sunguh/palawakng to be eaten together. New rice from rice harvested in the fields is usually wrapped in leaves abuatn to be subsequently divided to neighbors and local residents with a view to malapasi'. Stages are also marked by this ritual process as an expression to God (Jubata) that eating new rice has begun.

Mipis Tangke'atn is part of a farming stage that is marked by a customary ritual in a field led by Panyangahatn. This process is usually done while still in the atmosphere of singing or rice is still in the fields. This stage is also known as the process of raising rice to the house. Mipis banih also known as roah, is the final stage of the cultivation cycle as an expression of joy, friendship among others, as well as thanksgiving to $\mathrm{Gog}(\mathrm{Ne}$ 'Nange or Jubata) for the harvest of paddy fields. Mipis Banih usually begins with a customary ritual baremah led Panyangahatn. In this process, in addition to praying the seeds in a way that will be raised in the cottage (dango, the results obtained from the cultivation are also done eating together that brings relatives, relatives, neighbors, and acquaintances. The final stage of this cultivation process is also widely known by the term (feast) of rice gawae and or Naik Dango.

Based on the exposure of stages in the cultivation of Bauma Tahutn can be concluded that the Dayak mind really has a deep touch with the natural environment. Such thoughts are very socio-religious magic, Widjono (1998: 69). This is the underlying reality that, Dayak community is an integral part of the environment itself. This holistic insight makes the Dayak not to sort things out between humans and the natural surroundings, instead, they both have mutually supportive powers and powers to maintain the balance of the universe. Such thoughts, in everyday life, are implemented in traditional practices and ceremonies, as well as in their behavior towards natural resource management.

In the Dayak farming activities in utilizing the forest as a field area, it is not done as they please, there are a number of rules that must be obeyed, it is intended to keep the forests that are part of their lives are kept awake sustainability. In forest management basically, Dayak people always derived from the religious system. The essence contained in the religious system is to guide and emulate the Dayak community to always behave in harmony with the dynamics of the universe, so as to manifest the balance of the relationship between man and the natural environment.

In the context of management of forest resources with traditional wisdom, basically among Dayaks have certain ways to treat forest area. According to Bamba (1996: 14), the Dayaks view nature not as an asset or other property as a house together. The concept of a common house is seen in every ceremony that precedes certain activities related to the use of forests, where there is always permission or asks permission from forest dwellers to be worked on. The sound of birds or certain animals become a means of communication between humans and the inhabitants of nature.

According to the Dayak belief, when in the activity of farming, especially in choosing the location to be worked on, when encountering various constellations, it is necessary to do the ceremony by offering offerings with the intention that the spirits that have supernatural powers do not interfere with their lives either individually or in groups. These beliefs, as depicted, indicate that Dayaks have a deep contact with the myth, an event considered sacred, or an event directly experienced by the ancestors, although the time of the occurrence cannot be ascertained historically, the history of the event is for Dayaks serve as the norm of life. Such thinking creates their perception of the wisdom of managing forest resources (Widjono, 1995: 34).

The Dayak realm explains that, other than humans and other living beings living on earth, there is also another living figure in the universe. They call the place as Land above the sky, Land under the ground, Affairs of the Spirit. The god of the inhabitants of the land 
above the sky is depicted as the hornbill, the symbol of mightiness, the earth under the earth, depicted as the Dragon, the symbol of fertility (Widjono 1995: 35). The Dayaks, this universe has a code of conduct, as well as human relationships with residents in other lands, also have rules intended to maintain the continuity of those countries. While the laws of nature prevailing in the world is the embodiment of the order of the universe. Likewise, the social ethics and traditions of the hereditary community are the embodiment of the standard order of the universe (Widjono, 1995: 36). Even Measure (1994: 15), states that for Dayaks, the meaning of life does not lie in welfare, reality, or objectivity as understood by modern humans, but in the balance of the cosmos. Life is good when the cosmos remains in balance and in harmony. Every part of the cosmos (including humans and other creatures), according to the Measure has the obligation to maintain the balance of the universe. The mythical events for Dayaks are transcendental realities, meaning that the objectivity of the myths we have seen becomes clear that the environment is understood as everything exists in the environment, flora, fauna, water, earth, air and so on. The religious meaning of the surrounding environment is seen both in terms of objective and subjective.

\section{The Values of Local Wisdom Bauma Tahutn Tradition.}

In this farming activity with shifting cultivation, the Dayak tribe in utilizing the forest as a field area is not done as they please, there are a number of rules that must be obeyed, it is intended to keep the forests that are part of their lives sustained. In forest management basically, Dayak people always derived from the religious system. The essence contained in the religious system is to guide and emulate the Dayak community to always behave in harmony with the dynamics of the universe, so as to manifest the balance of the relationship between man and the natural environment. As for the values of local wisdom contained in the tradition of shifting cultivation (Bauma Tahutn) is among others.

First, the value of environmental conservation and care. In the context of management of forest resources with traditional wisdom, basically among Dayaks have certain ways to treat forest area. According to Bamba (1996: 14), the Dayaks view nature not as an asset or other property as a house together.

Second, the values of local wisdom in seeing the natural phenomenon. The Dayak people recognize natural phenomena in clearing land by utilizing various species of birds. There are several types of birds to determine the constellation of the Keto Bird, its body is small a big sound, the same as its name and rarely heard. According to the Dayak Kanayant belief that: (a) Keto birds carrying rice from the Lord's abode (in Kanayant terms called Jubata) to the world; (b) if the sound of the Keto bird sounds singular and only one voice speaks, the existing field may be done, and if there is so much noise the existing field should not be done; Bird Cece, her small voice body the same as her name and sound big enough. According to the Dayak people's trust Kanayant, Cece bird sounds a sign less or less good. This bird is believed to have a relationship with a very dreaded god (god of the land, the term Kanayant called kamang). If the sound of this bird is heard from the side, back, or front indicates: (a) on the way home will get into trouble; (b) when working on the fields, the fields will not work. Then if the sound of this bird is heard at night indicates: (a) there may be among families who will die; (b) the house or rice barn will burn; Adatn, the branches or branches of wood fall without any cause, it is believed will bring disaster. According to the Dayak belief, the existence of these birds is used to help in determining the time to plant rice.

Third, religious values (religious). Religious (religious) values can be seen from the stage of planting rice with shifting cultivation (Bauma Tahutn) which is always preceded by ceremonies to God (Jubata) both in clearing land, planting rice seeds until harvesting. These beliefs, as depicted, indicate that Dayaks have a deep contact with the myth, an event considered sacred, or an event directly experienced by the ancestors, although the time of the occurrence cannot be ascertained historically, the history of the event is for Dayaks serve as the norm of life. Such thinking creates their perception of the wisdom of managing forest resources (Widjono, 1995: 34). The Dayak realm explains that, other than humans and other living beings who live on earth, there are also other living figures in this universe. They call the place as Land above the sky, Land under 
the ground, Affairs of the Spirit. The god of the inhabitants of the land above the sky is depicted as the hornbill, the symbol of might, the earth beneath the soil, described as the Dragon, the symbol of fertility (Widjono 1995: $35)$.

Fourth, the value mutual cooperation and togetherness. This value can be from Bauma Tahutn's implementation. Bauma Tahutn is a unique culture because it has a philosophical meaning of togetherness and kinship. This value can be seen from the implementation of Bauma Tahutn, in the Dayak community, planting rice in shifting cultivation (Bauma Tahutn) is done by mutual cooperation (rotation), Bauma Tahutn can be followed by everyone.

\section{Conclusion}

Bauma Tahutn is a cropping pattern with shifting cultivation or in terms of shifting cultivation. The Dayak farming system uses land that is usually cultivated two to three times the growing season. The fact that traditions cultivate as an integral part explains the identity of Indigenous Dayak communities.

The stages in planting rice with cultivation (Bauma Tahutn) through several stages of Bahaupm is the first stage conducted in the cycle of farming activities by community communities. Baburukng is intended as a form of gratitude, asking for blessing as well as basic form (respect/permission) to the natural ruler by way of bapadah that will be done cultivation. Balala' is an important stage in which people practice abstinence. Ngawah is determine the location as well as bapadah by way of basampakng that will start Nugal through slashing activities. Nabas is the stage of clearing the land by slashing shrubs and a number of small diameter wood plants in the location to be covered. Nabank means (cutting down) a process that is done by cutting down the standing of a tree in a field location to be cleaned. Ngaradah is the stage of farming done by cutting or cutting branches and branches of wood that has been cut to be more orderly and look neat. Ngalaet/Ngaradak is very important and must be done to control the fire in the process of burning the fields. Nunu means burning. Ngalese' is the stage of cleaning the rest of the trees, branches and twigs on the fields after being burned by cutting and or collecting wood/twigs of burnt remains to be stacked and then burned again.

\section{Reference}

Arman, Syamsuni. 1989. Perladangan Berpindah Dan Kedudukannya Dalam Kebudayaan Suku-Suku Dayak Di Kalimantan Barat, Pontianak: Makalah di Sampaikan Dalam Dies Natalis XXX Dan Lustrum VI Universitas Tanjungpura.

Bamba, John, 1996. Pengelolaan Sumber Daya Alam: Menurut Budaya Dayak Dan Tantangan Yang Di Hadapi, Dalam Kalimantan Review, Nomor 15 Tahun V, Maret-April 1996, Pontianak.

Capra, F. (2002). Jaring-jaring Kehidupan, Visi Baru Epistimologi dan Kehidupan. Yogyakarta: Fajar Pustaka Baru.

Creswell, J. W. (2013). Research design: Qualitative, quantitative, and mixed methods approaches. (edisi ketiga).Thousand Oaks: Sage.

Keraf, A. S. (2010). Etika Lingkungan Hidup. Jakarta: Gramedia.

Mering, Ngo. 1990. Inilah Peladang, dalam: Prospek No 3 Tahun 1, 13 Oktober 1990.

Soedjito, Herwasono. 1999. Masyarakat Dayak: Peladang Berpindah dan Pelestarian Plasma Nutfah, Dalam Kusnaka Adimihardja (editor),Petani, Merajut Tradisi Era Globalisasi, Pendayaangunaan Sistem Pengetahuan Lokal Dalam Pembangunan, Bandung: Humaniora Utama Press.

Supriatna, N. 2016. Ecopedagogy, Membangun Kecerdasan Ekologis dalam Pembelajaran IPS. Bandung: PT. Remaja Rosda Karya.

Widjono, Roedy Haryo. 1995. Simpakng Munan Dayak Benuag, Suatu Kearifan Tradisional Pengelolaan Sumber Daya Hutan, Pontianak: Dalam Kalimantan Review, Nomor 13 Tahun IV, Oktober- Desember.

Widjono, 1998. Masyarakat Dayak Menatap Hari Esok, Jakarta: Gramedia Widiasarana Indonesia. 